\title{
PENGARUH ORIENTASI SERAT KOMPOSIT E-GLASS EPOXY TERHADAP SIFAT MEKANIK PEGAS DAUN TUNGGAL DENGAN METODE ELEMEN HINGGA
}

\author{
${ }^{1}$ Amirin Kusmiran , ${ }^{2}$ Akbar Sukman Pradhipta, ${ }^{3}$ Rita Desiasni \\ 1 Jurusan Fisika,Universitas Islam Negeri Alauddin Makassar \\ 2,3 Program Studi Teknik Metalurgi, Universitas Teknologi Sumbawa \\ amirin.kusmiran@uin-alauddin.ac.id
}

Diterima
Bulan Januari 2020
Diterbitkan
Bulan Februari 2020
Kata Kunci,
Pegas daun,
Komposit E-glas Epoxy,
Orientasi Serat,
Metode elemen hingga

\section{Diterima}

\begin{abstract}
Abstrak
Pegas daun tunggal merupakan salah satu sistem suspensi pada kendaraan yang berfungsi sebagai peredam getaran yang biasanya menggunakan baja. Satu jenis baja yang sering digunakan dalam pembuatan pegas daun tunggal adalah baja $55 \mathrm{Si}$. Namun, saat ini material komposit mulai digunakan sebagai material alternatif pengganti baja. Salah satu material komposit yang digunakan sebagai bahan pengganti baja yakni E-glass epoxy. Penelitian ini bertujuan untuk mengetahui perbedaan karakteristik pegas daun baja dan komposit e-glass epoxy. Selain itu, pengaruh orientasi arah serat terhadap deformasi, tegangan, dan safety factor pada pegas daun juga dilakukan dalam penelitian ini. Metode analisis yang digunakan adalah elemen hingga. Hasil penelitian menunjukan bahwa pegas daun komposit memiliki tegangan yang lebih rendah dibandingkan pegas daun baja. Pegas daun komposit e-glass epoxy variasi D (orientasi serat $45^{\circ} /-45^{\circ}$ ) menunjukan tegangan yang terendah dan safety factor tertinggi dengan nilai berturut turut $596 \mathrm{MPa}$ dan 1,4 .
\end{abstract}

\section{PENDAHULUAN}

Pegas daun merupakan komponen dari kendaraan yang berfungsi sebagai sistem suspensi yang terbuat dari baja seperti Baja EN45, EN47, 60Si7, 50Cr4V2, 55SiCr7, dan 50CrMoCV4 sebagaimana dinyatakan oleh Patunkar dan Dolas, 2013. Namun penggunaan material tersebut mulai dipertimbangkan dikarenakan ketersediaan bahan baku, dan tidak bersifat berkelanjutan. Pengembangan material pegas daun terus dilakukan, khususnya di bidang komposit. Selain memiliki karakteristik yang dibutuhkan, komposit juga memiliki salah satu karakteristik utama yang dibutuhkan pada pegas daun yaitu strain energy yang besar. Selain itu, isu lingkungan juga menjadi alasan untuk dilakukannya pengembangan komposit untuk aplikasi pegas daun.

Beberapa komposit telah dikembangkan untuk aplikasi pegas daun, seperti komposit e-glass/epoxy, graphite/epoxy dan carbon/epoxy (Pantukar dan Dolas, 2013). Diantara komposit tersebut, komposit e-glass epoxy merupakan komposit yang memiliki kekuatan yang hampir setara dengan baja dan memiliki fatigue life yang baik serta ekonomis. Namun, untuk

variasi geometri (Dhoshi, 2011). Namun untuk komposit dengan variasi orientasi serat masih sedikit dilakukan untuk aplikasi pegas daun. Sedangkan arah serat sangat berpengaruh terhadap kekuatan material pegas. Penelitian orientasi serat telah dilakukan oleh Gebremskel (2013) dan Galur dan Vijayarang (2006). Namun dalam penelitian yang dilakukan, orientasi serat yang digunakan adalah arah serat satu direksi atau unidirection. Sehingga pengembangan orientasi serat multidirection perlu dilakukan untuk pengembangan pegas daun komposit dengan menggunakan pendekatan secara numerik.

Oleh karena itu, pendekatan numerik banyak diterapkan pada Metode Elemen Hingga (Finite Element Method) yang telah terintegrasi dengan perakat lunak Ansys. Sehingga tujuan dari penelitian ini mampu mengetahui pengaruh multi orientasi serat 
komposit E-Glass Epoxy terhadap sifat mekanik pegas daun tunggal secara komputasi.

\section{LANDASAN TEORI}

\section{Pagas daun tunggal}

Pegas daun tunggal biasanya terdiri dari sebuah pelat baja yang mempunyai kelengkungan di sepanjang daun pegas. Pegas daun tunggal memiliki karateristik kelengkungan bagian tengah pegas yang lebih tebal dan meruncing hingga kebagian ujung pegas . Pegas daun tipe ini biasa mempunyai kekauan yang rendah. Hal ini memberikan kemampaun pengendaraan yang lembut dan pengangkutan barang yang baik. Pegas daun tipe ini juga tidak memiliki karakteristik gangguan dan gesekan statis seperti pada pegas daun ganda (multi leaf springs) sebagaimana yang dinyatakan oleh Saini, P., dkk, 2013.

\section{Perhitungan Tegangan dan Defleksi Pegas Daun}

Menurut Bhandari (1994), perhitungan tegangan dan defleksi pada pegas daun dengan lebar daun yang seragam dapat digunakan persamaan sebagai berikut:

$$
\begin{aligned}
& \sigma=\frac{6 \mathrm{PL}}{\mathrm{nbt}^{2}} \\
& \delta=\frac{12 \mathrm{PL}^{3}}{\mathrm{Ebt}^{3}(3 n f+2 \mathrm{ng})}
\end{aligned}
$$

dimana $n_{f}$ adalah jumlah daun extra full-length, $n_{g}$ adalah jumlah daun graduated-length termasuk master leaf, $n$ adalah jumlah total daun, $b$ adalah lebar setiap daun $(\mathrm{mm}), t$ adalah ketebalan setiap daun $(\mathrm{mm}), L$ adalah panjang cantilever atau setengah panjang pegas semi-eliptical $(\mathrm{mm}), P$ adalah gaya yang bekerja pada ujung pegas $(\mathrm{N}), P_{f}$ adalah bagian gaya $P$ yang bekerja pada daun-daun extra full-length $(\mathrm{N}), P_{g}$ adalah bagian gaya $P$ yang bekerja pada daun-daun graduated-length $(\mathrm{N}), E$ adalah modulus elatisitas $\left(\mathrm{N} / \mathrm{m}^{2}\right)$

\section{Komposit}

Komposit merupakan penggabungan dari dua material atau lebih, yang dibentuk pada skala makroskopik dan menyatu secara fisik untuk memperoleh sifat-sifat baru yang tidak dimiliki oleh material pembentuknya. Dalam penggabungan antara serat dan resin, serat akan berfungsi sebagai penguat (reinforcement) dan biasanya mempunyai kekuatan dan kekakuan tinggi, sedangkan resin berfungsi sebagai perekat atau matrik untuk menjaga posisi serat, mentransmisikan gaya geser dan juga berfungsi sebagai pelapis serat. Matrik biasanya mempunyai kekuatan relatif rendah tetapi ulet, karena itu serat secara dominan akan menentukan kekuatan dan kekakuan komposit. Semakin kecil ukuran serat, maka akan memberikan perekatan dan kekuatan yang semakin baik, karena rasio antara permukaan dan volume serat semakin besar (Riedel, 1999).

Kekuatan komposit sangat dipengaruhi oleh beberapa faktor seperti jenis, geometri, arah, distribusi, dan kandungan serat. Berdasarkan teori Rule of Mixture (ROM), kekuatan komposit meningkat seiring dengan penambahan kandungan serat mencapai $60-70 \%$ (Sanadi dkk., 1986). Pertimbangan pemilihan serat untuk komposit juga sangat dipengaruhi oleh beberapa parameter diantaranya adalah nilai kekuatan dan kekakuan komposit yang diinginkan, perpanjangan ketika patah, stabilitas termal, ikatan antara serat dan matrik, perilaku dinamik.

Faktor-faktor yang harus diperhatikan supaya mendapatkan kekuatan komposit yang optimal seperti letak serat, panjang serat, bentuk serat,dan ikatan serat dan matriks. Dalam Pembuatan komposit, tata letak dan arah serat dalam matrik akan menentukan kekuatan mekanik komposit. Letak dan arah dapat mempengaruhi kinerja suatu komposit. Tata letak dan arah serat diklasifikasikan menjadi tiga bagian yaitu one dimensional reinforcement, two dimensional reinforcement, dan One dimensional reinforcement.

Komposit e-glass epoxy merupakan komposit polimer matriks komposit atau biasa dikenal sebagai glass fiber reinforced polymer (GFRP). GFRP memiliki kualitas yang sangat baik seperti rasio kekuatan dan kekuatan yang hampir mendekati logam. Selain itu, komposit ini juga ringan, transparan, tidak berwarna, dan tidak ada batas ukuran objek dalam pembuatan. Oleh karena itu, penggunaan GFRP sering digunakan untuk aplikasi industri.

Pada aplikasi pegas daun, GRFP sering dibandingkan dengan pegas baja. Dalam penelitian yang dilakukan Saini (2013) menunjukan salah satu keunggulan yang dimiliki oleh komposit e-glass epoxy dibandingkan baja dan komposit carbon epoxy dan graphite epoxy yaitu pada tegangan yang dihasilkan pada pegas dari Gambar 1 terlihat tegangan e-glasss epoxy jauh lebih baik dikarenakan modulus elastisitas e-glass epoxy lebih rendah dibandingkan graphite epoxy dan carbon epoxy (Calister dan Wiley, 2007).

\section{Metode Elemen Hingga}

Metode elemen hingga merupakan salah satu metode numerik yang dapat digunakan untuk menyelesaikan persamaan differensial yang berkaitan 
dengan masalah mekanika kontinum. steady, transient, linier, atau permasalahan nonlinier pada analisis tegangan, perpindahan kalor aliran fluida, dan permasalahan elektromagnetik dimungkinkan dapat dianalisa. Kontinum atau benda dibagi-bagi menjadi beberapa bagian yang lebih kecil, maka elemen kecil ini disebut elemen hingga. Proses pembagian kontinum menjadi elemen hingga disebut proses diskretisasi (pembagian) pada suatu bidang.

Suatu bidang yang luas dengan dimensi yang tidak teratur, dipotong-potong berbentuk segi tiga atau bentuk segi empat yang beraturan. Bidang yang dengan dimensi tidak beraturan tadi disebut kontinum, bidang segitiga atau segi empat beraturan disebut elemen hingga. Dan banyak lagi persoalan yang identik dengan hal diatas. Maka dari sini dapat dikatakan bahwa elemen hingga merupakan elemen diskrit dari suatu kontinum yang mana perilaku strukturnya masih dapat mewakili perilaku struktur kontinumnya secara keseluruhan. Pendekatan dengan elemen hingga merupakan suatu analisis pendekatan yang berdasarkan asumsi peralihan atau asumsi tegangan, bahkan dapat juga berdasarkan kombinasi dari kedua asumsi tadi dalam setiap elemennya. Gambar 1 merupakan contoh penggambaran pembagian suatu benda ke dalam bagian kecil-kecil atau elemen.

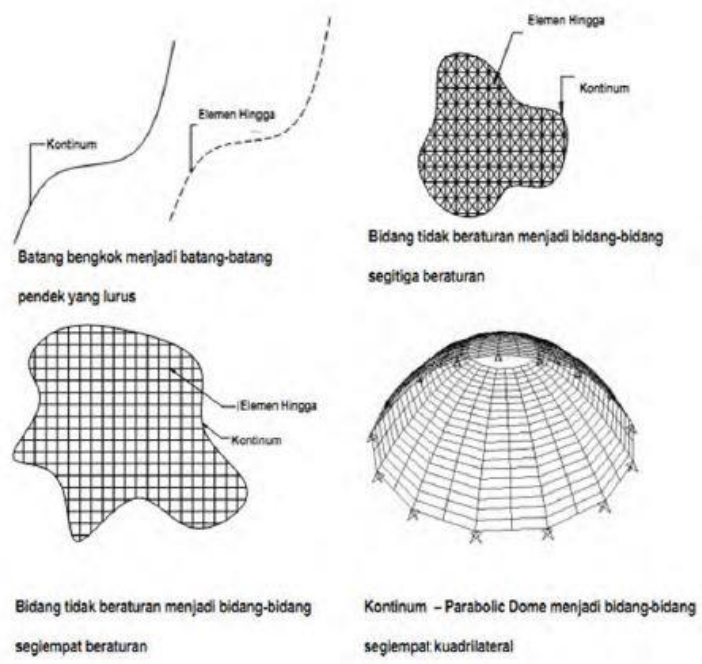

Gambar 1. Diskretisasi suatu koninum pada Metode Elemen Hingga (Wever dan Johnston, 1993).

Metode elemen hingga ini yang akan digunakan untuk menganalisis sifat mekanik baja dengan komposit $e$ glass epoxy dengan menggunakan perangkat lunak Ansys.

\section{METODE PENELITIAN}

Diagram alir penelitian pada Gambar 2 menunjukkan proses yang digunakan untuk menganalisis sifat mekanik komposit yang telah didesain. Hasil pemodelan dari komposit pegas daun dibandingkan dengan hasil pemodelan yang diperoleh dari baja pegas daun tipe 55Si7. Model sifat mekanik yang dibandingkan yakni total deformasi yang dihasilkan oleh komposit pegas daun dengan baja pegas daun tipe $55 \mathrm{Si} 7$.

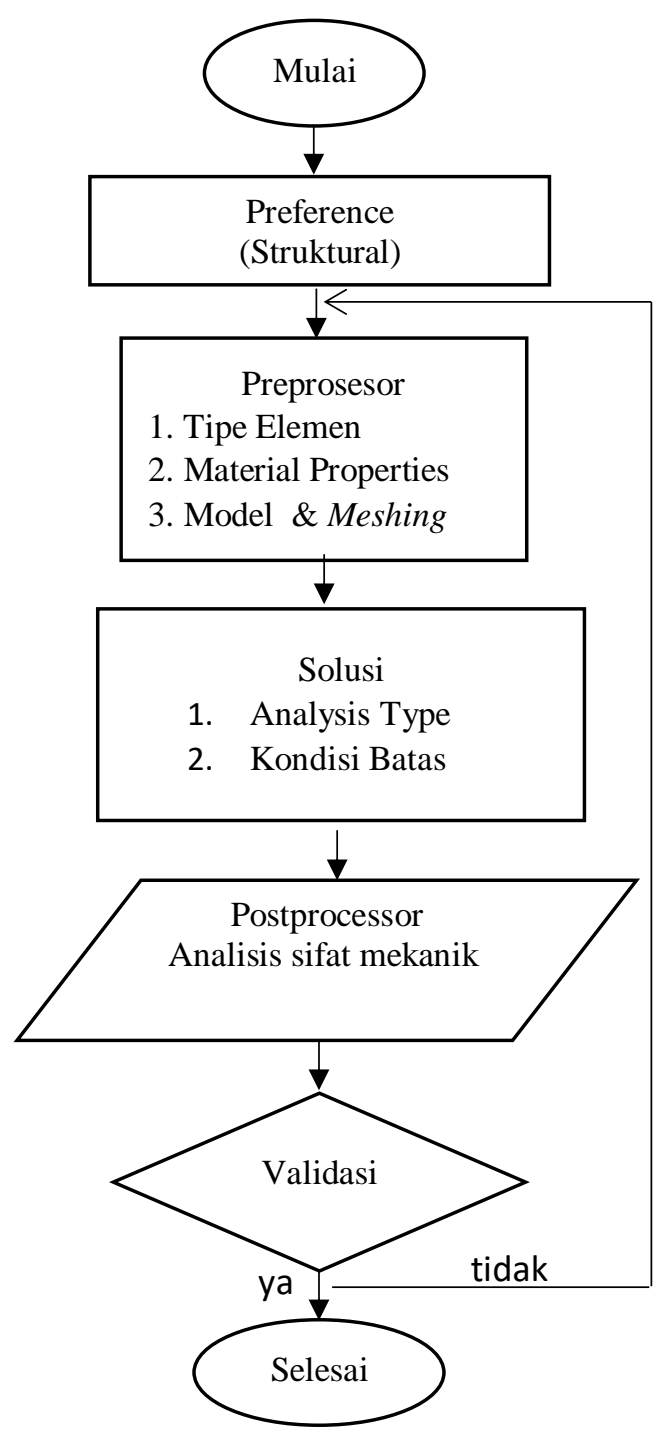

Gambar 2. Prosedur analisis sifat mekanik komposit dengan Metode Elemen Hingga. 
Permodelan pegas daun dilakukan dengan menggunakan perangkat lunak Ansys yang merupakan software berbasis metode elemen hingga atau finite element. Penelitian menggunakan dua jenis material yaitu baja $55 \mathrm{Si} 7$ dan e-glass/epoxy. Untuk material baja, data yang digunakan merupakan hasil penelitian karlus, dkk (2014), sedangkan material e-glass/epoxy merupakan hasil permodelan menggunakan ACP (pre) yang merupakan salah satu tools pada Ansys. Pada permodelan ini terdapat beberapa input diantaranya properties material, geometri, model dan setup. Pada Properties material komposit e-glass/epoxy diambil berdasarkan hasil simulasi menggunakan software autodesk composite design simulator seperti yang ditunjukan pada Gambar 3.

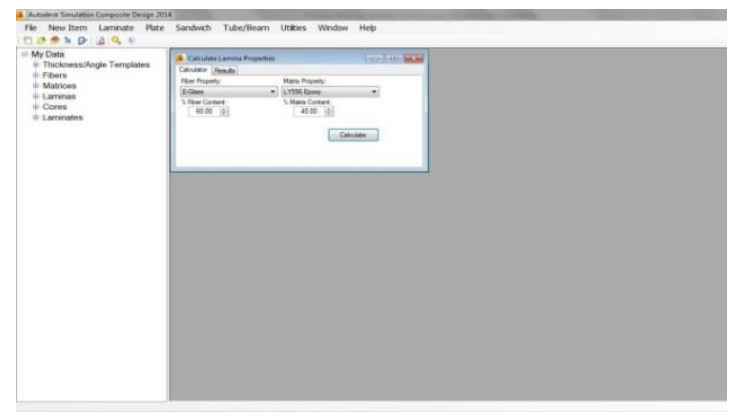

Gambar 3. Prosedur pembuatan e-glass/epoxy.

Setelah mendapatkan properties material, kemudian dilakukan konstruksi pegas daun menggunakan ANSYS Design Modeler setelah itu dilakukan proses meshing dengan jumlah elemen dan node secara beturut-turut ialah 628 dan 955. Setelah tahapan ini selesai tahapan selanjutnya yakni melakukan desain komposit atau tahap preprosesing pada ACP prepost dengan variasi seperti pada tabel 1 .

Tabel 1. Variais komposit.

\begin{tabular}{ccccc}
\hline Jenis & $\%$ Vf : & $\begin{array}{c}\text { Arah } \\
\text { KVm }\end{array}$ & $\begin{array}{c}\text { Jumlah } \\
\text { Serat }\end{array}$ & $\begin{array}{c}\text { Ukuran } \\
\text { layer }\end{array}$ \\
\hline Variabel A & $0: 100$ & - & - & $8.2 \mathrm{~mm}$ \\
Variabel B & $100: 0$ & $0^{\circ}$ & 41 & $0.2 \mathrm{~mm}$ \\
Variabel C & $70: 30$ & $0^{\circ}$ & 41 & $0,2 \mathrm{~mm}$ \\
Variabel D & $70: 30$ & $\begin{array}{c}45^{\circ} /- \\
45^{\circ}\end{array}$ & 41 & $0,2 \mathrm{~mm}$ \\
& & & \\
Variabel E & $70: 30$ & $0^{\circ} / 90^{\circ}$ & 41 & $0,2 \mathrm{~mm}$
\end{tabular}

Setelah itu, dilakukan pembentukan arah serat pada komposit pegas daun. Arah serat yang digunakan dalam penelitian ini adalah $0^{\circ}, 45^{\circ},-45^{\circ}$, dan $90^{\circ}$ seperti yang terlihat pada Gambar 4. Sudut pengambilan gambar diambil sepanjang sumbu y dan garis panah hijau menunjukan arah serat pada komposit. Setelah tahapan pembentukan arah serat dilakukan sesuai

dengan jumlah dan arah yang telah ditunjukan pada Tabel 1 .

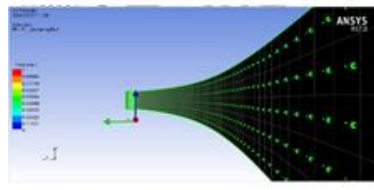

(a)

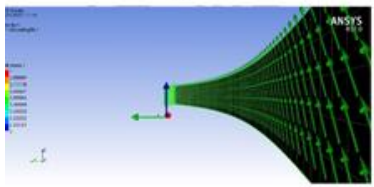

Gambar 4. Arah serat komposit a) Ply angle $\left.0^{\circ}, \mathrm{b}\right)$ Ply angle $90^{\circ}$, c) Ply angle $45^{\circ}$ d) Ply angle $-45^{\circ}$

Gambar 4 diatas menunjukan arah serat yang digunakan pada desain komposit. Setelah tahapan ini selesai tahapan selanjutnya yakni melakukan analisis statik atau disebut dengan analisis tegangan.

\section{HASIL DAN PEMBAHASAN}

Setelah fabrikasi komposit, pembebanan diberikan pada setiap variasi sebesar $6145 \mathrm{~N}$. Pembebanan ini nantinya akan menghasilkan nilai tegangan, dan deformasi pada pegas daun. Nilai pembebanan ini didapatkan berdasarkan spesifikasi kendaraan Daihatsu Gran Max Pick Up 3SZ-VE. Gaya diberikan dibagian tengah seperti pada Gambar 5.

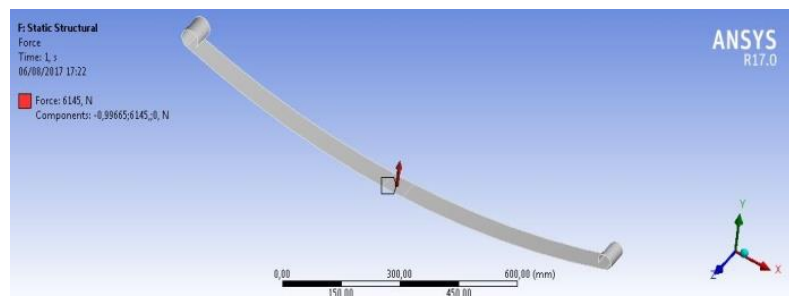

Gambar 5. Pembebanan Pegas daun.

Pada setiap variasi orientasi serat, jumlah lapisan atau lamina pada permodelan dibuat sama. Sehingga parameter utama pada penelitian ini adalah pengaruh dari orientasi serat terhadap sifat mekanik komposit yang dilihat dari nilai stress, strain dan deformasi yang dihasilkan ketika pemberian beban diberikan pada setiap variasi yang menghasilkan deformasi total yang berbeda-beda sebagaimana diperlihatkan pada Gambar 6. 


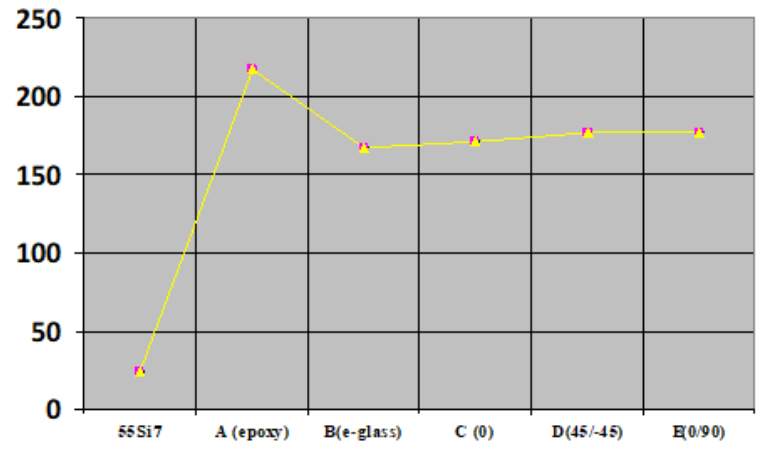

Gambar 6. Total deformasi pegas daun.

Berdasarkan grafik deformasi yang ditunjukan pada Gambar 6, Baja 55Si7 merupakan material pegas yang menghasilkan nilai deformasi terendah hal ini dikarenakan baja memiliki kekakuan yang lebih tinggi dibandingkan material lainya. Hal ini terlihat dari young modulus baja yang mencapai $210.00 \mathrm{MPa}$. Sedangkan komposit memiliki young modulus yang rendah sehingga menunjukan bahwa material ini lebih elastis dibandingkan baja.

Sifat elastis komposit juga terlihat dari tingkat deformasi yang dihasilkan yang rata-rata mencapai 171 mm hingga $177 \mathrm{~mm}$.

Selain itu, dibandingkan dengan pegas daun komposit searah, komposit dengan dua arah menunjukan nilai deformasi tertinggi. Hal ini sesuai dengan penelitian yang dilakukan oleh Munasi (2011) yang menyatakan tingkat deformasi tertinggi akan ditunjukkan oleh komposit dua arah. Hal ini dikarekan orientasi serat dua arah akan menyebabkan berkurangnya gaya tegak lurus yang bekerja sehingga menghasilkan kekuatan tarik yang kecil. Secara visualisasi sifat mekanika material tegangan pegas daun tunggal diperlihatkan pada Gambar 7.

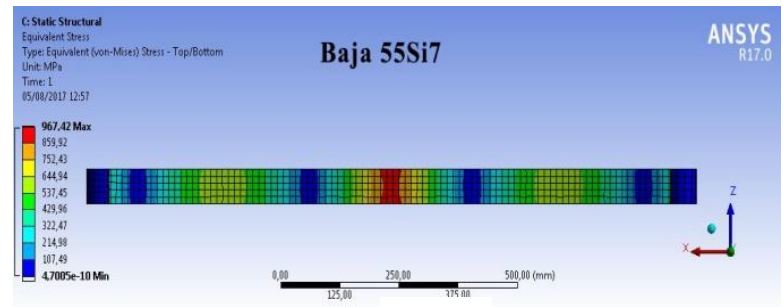

(a)

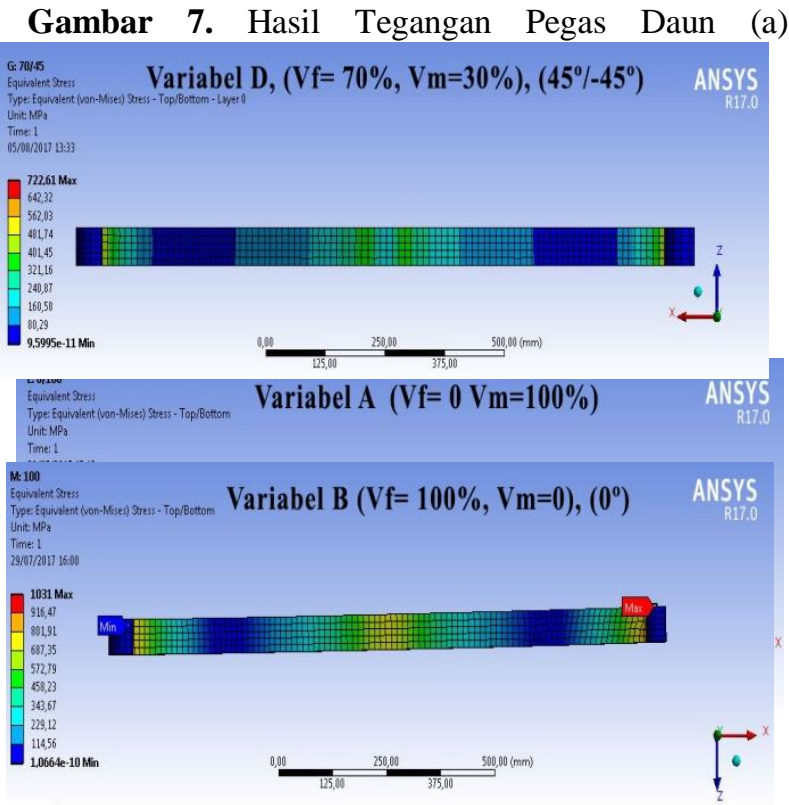

Baja55Si7, (b) Variabel A, (c) Variabel B, (d) Variabel C, (e) Variabel D, (f) Variabel E.

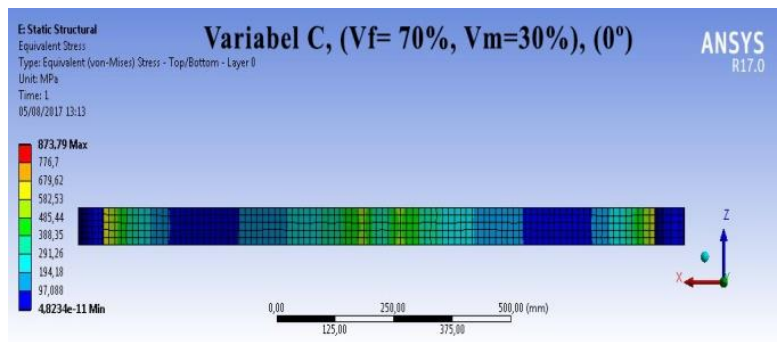

Gambar 7 merupakan hasil tegangan von misses pada setiap pegas daun. Dari gambar terlihat bahwa pegas daun setiap material memiliki letak tegangan maksimum yang berbeda beda. Untuk pegas dan baja terlihat memiliki tegangan maksimum pada bagian tengah sedangkan untuk material lainya memiliki tegangan maksimum pada bagian ujung pegas. Untuk itu dalam analisis akan dilakukan pada bagian tengah dan bagian ujung pegas.

\section{PENUTUP}

\section{Kesimpulan}

Berdasarkan penelitian yang telah dilakukan, dapat diambil kesimpulan sebagai berikut : Pegas daun baja. Pegas daun baja memiliki tegangan kritis pada tengah pegas sedangkan pegas daun komposit terletak pada ujung pegas; Variasi serat pada pegas daun komposit $e$ glass/epoxy berpengaruh tegangan dan deformasi yang dihasilkan. Tegangan dan deformasi komposit tertinggi ditunjukan pada pegas daun. Sedangkan pada tegangan 
dan deformasi terendah ditunjukan pada komposit dengan arah serat dua arah yaitu pada variabel D dan E.

\section{REFERENSI}

Callister, W.D. and Wiley, J.(2007).Material science. Engineering: An Introduction.

Dhoshi, N. P., Ingole, N. K., \& Gulhane, U. D. (2011). Analysis and modification of leaf spring of tractor trailer using analytical and finite element method. International Journal of Modern Engineering Research (IJMER), 1(2), 719-722.

Gebremeskel, S. A. (2013). Design, simulation, and prototyping of single composite leaf spring for light weight vehicle. Global Journal of Research In Engineering, 12(7-A).

Gulur S., S.S. and Vijayarangan, S. (2006). Mono composite leaf spring for light weight vehicledesign, end joint analysis and testing. ISSN 1392-1320 MATERIALS SCIENCE (MEDŽIAGOTYRA). Vol. 12, No. 3.

Patunkar, M.M. dan D. R. Dolas. (2013). Experimental Investigation and FEA of Mono Composite Leaf Spring Under the Static Load Condition. International Journal of Mechanical Engineering \& Computer Application. Volume 1 No. 7: $130-139$.

Riedel U., Nickel J., Herrmann A.S. (1999). High Performance Applications Of Plant Fibres In Aerospace And Related Industries. German Aerospace Center (DLR), Germany.

Saini, P., Goel, A., \& Kumar, D. (2013). Design and analysis of composite leaf spring for light vehicles. International journal of innovative research in science, engineering and technology 2(5).

Weaver, W., P. R. Johnston. (1993). Elemen Hingga Untuk Analisis Struktur. Edisi Kedua. PT.Eresco. Jakarta. 